\title{
Penggunaan $N$-mers Frequency pada Analisis Barisan DNA
}

\author{
Khoirul Umam ${ }^{1 *}$, Rahmat Sagara ${ }^{2}$ \\ 1,2 Program Studi Matematika Bisnis, Fakultas Bisnis, Institut Teknologi dan Bisnis Kalbis, \\ Jl. Pulomas Selatan Kav. 22, Jakarta Timur 13210, Jakarta, Indonesia \\ * Penulis Korespondensi. Email: khoirul.umam@kalbis.ac.id
}

\begin{abstract}
ABSTRAK
Salah satu metode untuk menganalisis barisan DNA adalah menggunaan $N$-mers Frequency. $N$-mers Frequency termasuk metode data mining pada barisan DNA, dimana barisan DNA yang merupakan data string "ACGT" akan diubah menjadi data numerik. N-mers Frequency pada tulisan ini menggunakan $N=3$. Hal ini disebabkan karena pada proses sintesis protein, tRNA akan membawa tiga basa nekleotida (anti kodon) yang akan dipasangkan dengan tiga basa nekleotida (kodon) pada pita mRNA. Dalam hal ini mRNA dibentuk dari duplikasi barisan DNA. Studi ini dilakukan untuk mengetahui akurasi dari penggunaan N-mers Frequency. Untuk menghitung Akurasi penggunaan N-mers Frequency, dilakukan tahapan seperti berikut: (1) pengumpulan data barisan DNA, (2) N-mers Frequency, (3) matriks jarak, (4) pengelompokan menggunakan algoritma K-means++, PAM, AGNES, dan DIANA, (5) menghitung akurasi, dan (6) kesimpulan. Akurasi dari Penggunaan N-mers Frequency pada penelitian ini adalah 100\%, dengan menggunakan data 100 barisan DNA yang telah diketahui jenisnya, yaitu: virus HPV, virus Ebola, virus Marburg, dan virus Zika.
\end{abstract}

Kata Kunci:

N-mers Frequency; K-means++; Data Mining; Barisan DNA

\section{ABSTRACT}

$N$-mers Frequency is a method for analyzing DNA sequences. It is a data mining method in the DNA sequence. The DNA sequence which is the string data, "ACGT". It will be converted into numerical data. The $N$ of $N$-mers Frequency is determined that $N=3$. It is because the tRNA protein synthesis process will carry three nucleotide bases (anti-codons) which will be paired with three nucleotide bases (codons) in the mRNA band which is formed by duplicating rows of DNA codes. This study, conducted to determine the accuracy of the use of N-mers Frequency. For calculate of the accuracy, steps are performed as follows: (1) collection of DNA sequences data, (2) N-mers Frequency, (3) distance matrix, (4) grouping using K-means++, PAM, AGNES and DIANA algorithms, (5) calculate the accuracy, and (6) conclusions. The accuracy of the use of N-mers Frequency in this study is $100 \%$, with using data from 100 DNA sequences which known their types, i.e., HPV virus, Ebola virus, Marburg virus, and Zika virus.

Keywords:

N-mers Frequency; k-Mean++; Data Mining; DNA Sequences

e-ISSN: 2656-1344 (C) 2020 K. Umam, R. Sagara| Under the license CC BY-NC 4.0

Diterima: 30 Desember 2019| Disetujui: 4 Maret 2020|Online: 08 Maret 2020 
Format Sitasi:

K. Umam and R. Sagara, "Penggunaan N-mers Frequency pada Analisis Barisan DNA," Jambura J. Math., vol. 2, no. 2, pp.73-86, 2020.

\section{Pendahuluan}

Seiring berkembangnya teknologi dan semakin murahnya biaya sequencing DNA, banyaknya data barisan DNA menjadi tak terbendung. Data dari National Human Genome Research Institute pada Gambar 1 menunjukkan bahwa biaya untuk per Megabase barisan DNA pada tahun 2015 sekitar \$0.01. Biaya ini merupakan hal sangat murah dibandingkan biaya pada tahun sekitar tahun 2001 yang biayanya hampir mencapai \$10.000 [1].

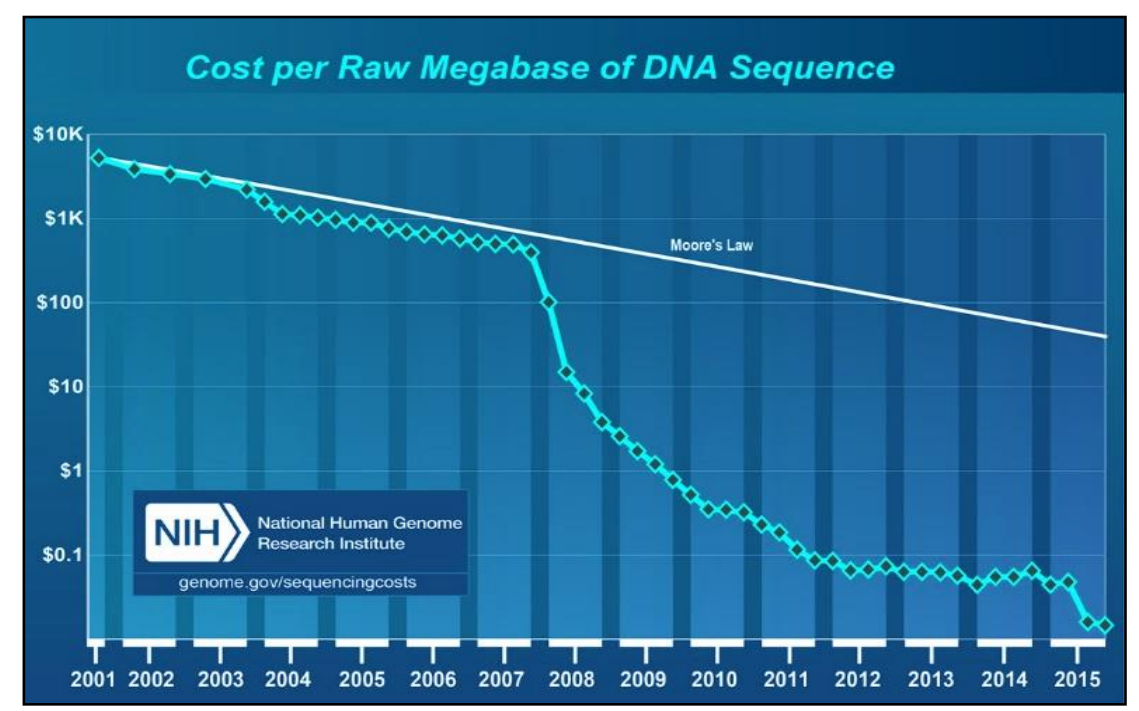

Gambar 1. Biaya per megabase barisan DNA

Pada laboratorium modern dengan mesin Polymerase Chain Reaction (PCR) yang mahal dapat menganalisis genom manusia sebanyak 3 miliar pasangan basa DNA dalam beberapa jam. Di tambah lagi penemuan mini PCR oleh Kraves pada tahun 2014, yang bisa dikatakan sebagai alat tes DNA personal yang bisa jalan dengan baterai solar. Penemuan ini membuat biaya sequencing DNA menjadi semakin murah. Semakin murahnya biaya sequencing DNA menjadikan laju banyaknya data barisan DNA sangat tinggi.

Pada Gambar 2 ditunjukkan bahwa data dari National Center for Biotechnology Information (NCBI) pada bulan desember 2016, terdapat sekitar 224 milyar base pairs DNA dari sekitar 200 juta entri barisan DNA. Jika ditambahkan dengan DNA data base sejenis seperti European Molecular Biology Laboratory (EMBL), DNA Data Bank of Japan (DDBJ) dan National Health $\mathcal{E}$ Medicine Big Data (Nanjing) Center, banyaknya base pairs DNA akan jauh melebihi 224 milyar [2].

Data tersebut menunjukkan bahwa studi tentang bioinformatics berkembang sangat pesat. Pada 2017, Nanjing Center sedang membangun gigantic DNA database. Melalui kerja sama dengan The State-Owned Yangzi Group, Southeast University and Nanjing 
Medical University, Nanjing Center menargetkan akan merekam informasi kesehatan dan medis dari 80 juta orang melalui sequencing DNA. Sampel barisan DNA tersebut akan diambil bertahap sekitar 400.000 sampai 500.000 pertahun. Database tersebut dibangun untuk mempelajari mutasi genetik yang terkait dengan penyakit mematikan, mencari dampak interaksi antara gen dan masalah lingkungan pada kesehatan manusia dan memberikan dukungan statistik untuk diagnosis dan pengobatan penyakit mematikan [3].

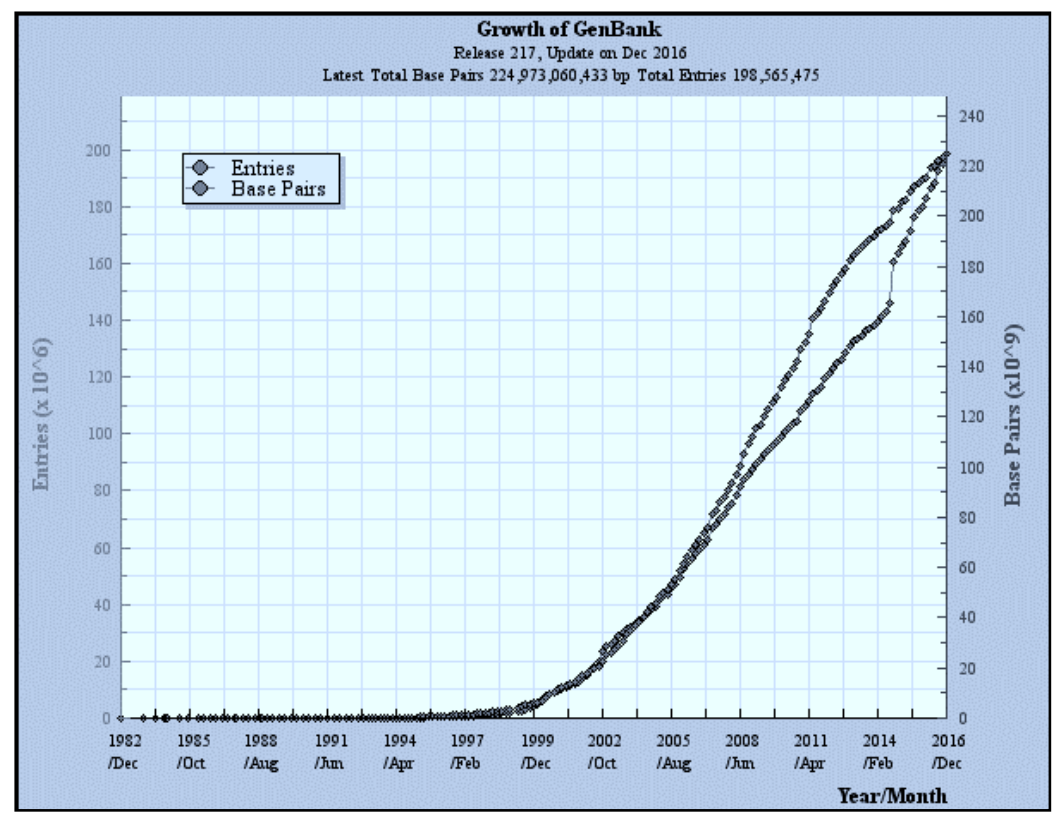

Gambar 2. Pertumbuhan data barisan DNA dari GenBank.

Untuk menganalisis barisan DNA, terutama yang berhubungan dengan kesehatan manusia diperlukan keakuratan yang tinggi. Salah satu metode data mining barisan DNA adalah metode $N$-mers Frequency [4][5]. Tulisan ini bertujuan untuk melihat akurasi penggunaan $\mathrm{N}$-mers Frequency dalam analisis barisan DNA. Untuk melihat akurasi penggunaan $\mathrm{N}$-mers Frequency, data barisan DNA yang sudah diketahui kelompoknya akan diacak, kemudian akan dikelompokkan kembali menggunakan algoritma K-mean++, PAM (Partitioning Around Medoid), AGNES (Agglomerative Nesting) dan DIANA (Divisive Analysis).

\section{Metode}

Barisan DNA merupakan barisan data string. Salah satu cara untuk menganalisis barisan DNA adalah mengubah data string menjadi data numerik. Pada tulisan ini diusulkan penggunaan $\mathrm{N}$-mers Frequency dalam analisis barisan DNA. Tulisan ini fokus pada perhitungan akurasi penggunaan $N$-mers Frequency. Untuk menghitung akurasi penggunaan $N$-mers Frequency dilakukan tahapan penelitian berikut: (1) pengumpulan data barisan DNA, (2) N-mers Frequency, (3) matriks jarak, (4) pengelompokan menggunakan algoritma K-means++, PAM, AGNES, dan DIANA, (5) menghitung akurasi, dan (6) kesimpulan. Tahapan tersebut dapat dilihat pada Gambar 3. 


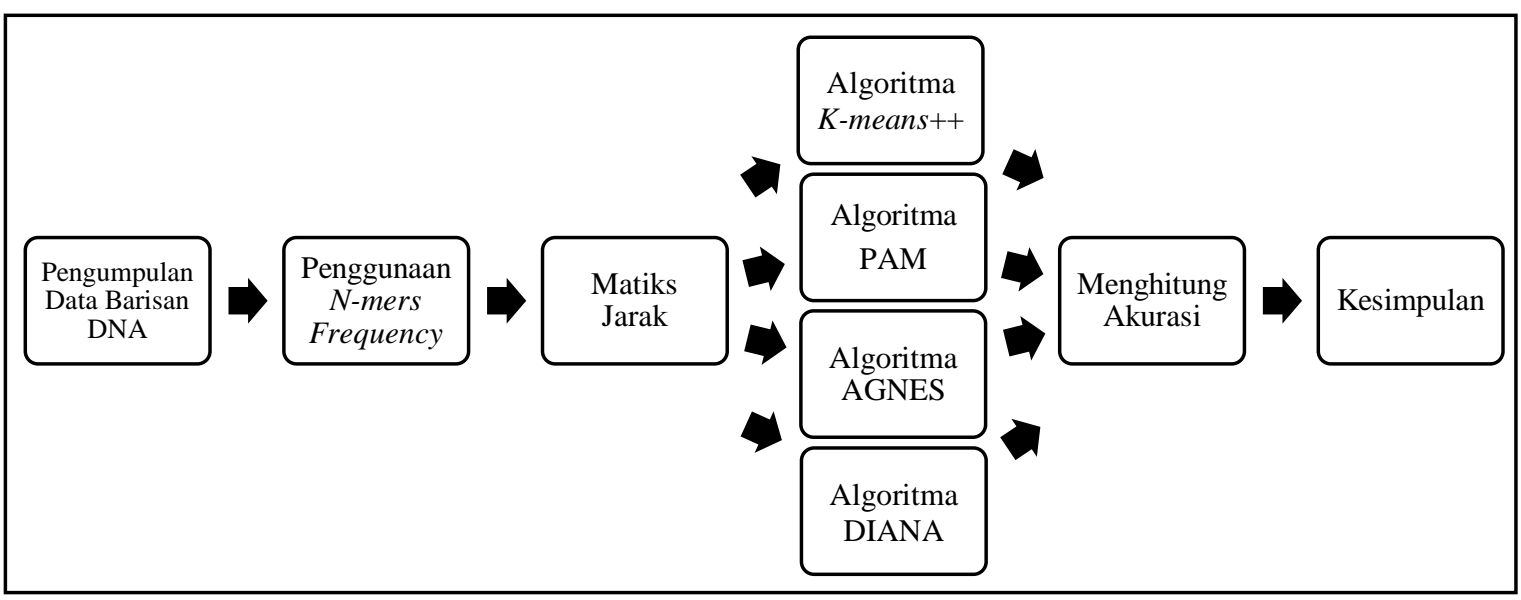

Gambar 3. Tahapan penelitian

Tahapan-tahapan penelitian yang tercantum pada Gambar 3, dipaparkan secara gambling pada sub-sub bab berikut.

\subsection{Pengumpulan Data Barisan DNA}

Data yang digunakan sebanyak 100 barisan DNA yang berbeda yang terdiri dari 25 barisan DNA virus Human Papillomavirus (HPV) [6], 25 barisan DNA virus Ebola [7], 25 barisan DNA virus Marburg [8], dan 25 barisan DNA virus Zika [9]. Pemilihan data virus tersebut didasarkan pada sifat virus yang berbahaya bagi manusia, bahkan ada yang menyebabkan kematian.

Data barisan DNA 4 kelompok virus tersebut diperoleh dari National Center for Biotechnology Information (NCBI). Barisan-barisan DNA tersebut berupa data complete genome dengan format FASTA [9]. Data barisan DNA sebanyak 100 dikumpulkan dalam format FASTA yang disimpan dalam format file "txt", kemudian diberi nama "data100.txt". Format FASTA diawali symbol " $>$ ", satu baris deskripsi, kemudian diikuti oleh barisan DNA yaitu A, C, G, dan T. Panjang barisan DNA pada masingmasing barisan DNA berkisar antara 7.000 bp sampai 20.000 bp. Contoh barisan DNA dengan format FASTA dapat dilihat pada Gambar 4.

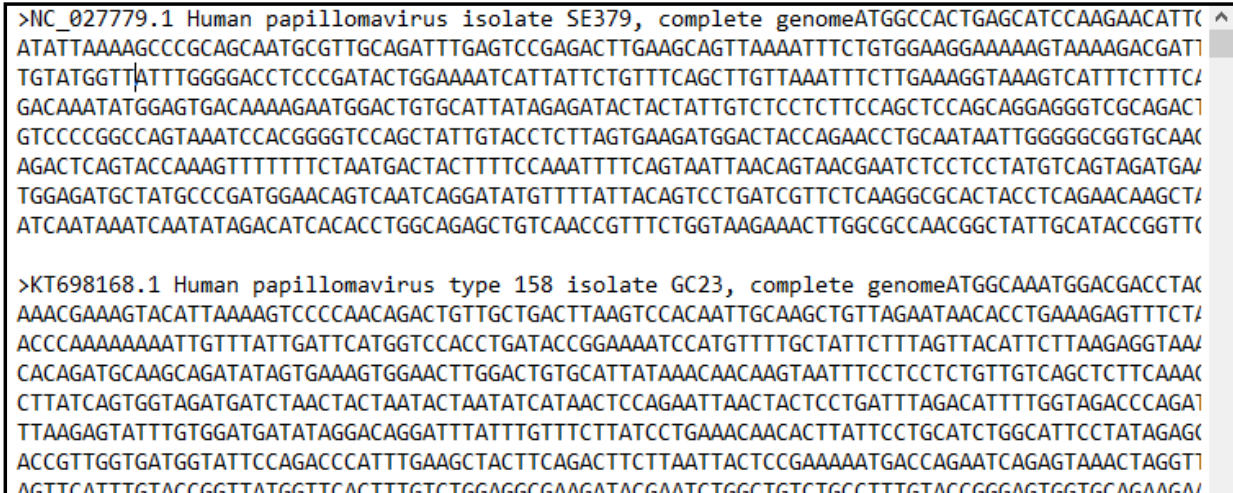

Gambar 4. Contoh barisan DNA dengan format FASTA 


\subsection{Penggunaan $N$-mers Frequency}

Data barisan DNA dalam format FASTA berupa data string, sehingga perlu untuk melakukan data mining dengan mengubah data string tersebut kedalam bentuk numerik. Salah satu cara mengubah data dari bentuk string menjadi numerik dilakukan dengan menggunakan N-mers Frequency [4]. N-mers Frequency digunakan untuk menghitung banyaknya pola kemunculan $N$ pasangan basa nukleotida yang sama dari suatu barisan DNA, dengan pola kemunculan sebanyak $4^{N}$ dengan $N \geq 1$. Dalam hal ini, angka 4 adalah banyaknya basa nekleotida pada DNA, yaitu Adenine (A), Cytosine (C), Guanine (G) dan Thymine (T) [10].

Dalam proses sintesis protein, tRNA akan membawa tiga basa nekleotida (anti kodon) yang akan dipasangkan dengan tiga basa nekleotida (kodon) pada pita mRNA yang dibentuk dari duplikasi barisan kode DNA. Oleh karena itu, pada N-mers Frequency ditentukan nilai $N=3$, sehingga dimensi data akan menjadi $4^{3}=64$. Dengan kata lain, data akan memiliki 64 dimensi, yaitu: AAA, AAC, AAT, AAG, ACA, ACC, ACT, ACG, ATA, ATC, ATT, ATG, AGA, AGC, AGT, AGG, CAA, CAC, CAT, CAG, CCA, CCC, CCT, CCG, CTA, CTC, CTT, CTG, CGA, CGC, CGT, CGG, GAA, GAC, GAT, GAG, GCA, GCC, GCT, GCG, GTA, GTC, GTT, GTG, GGA, GGC, GGT, GGG, TAA, TAC, TAT, TAG, TCA, TCC, TCT, TCG, TTA, TTC, TTG, TGA, TGC, TGT, TGG, TTT [11].

Syntax untuk perhitungan $N$-mers Frequency pada software $\mathrm{R}$ menggunakan fungsi oligonucleotide Frequency pada library "Biostrings". Syntax untuk N-mers Frequency dengan $N=3$ pada software R ditunjukkan pada Gambar 5 .

$$
\text { eks }=\text { oligonucleotideFrequency }(\operatorname{reads}[1: 100] \text {, width }=3 \text { ) }
$$

Gambar 5. Syntax untuk N-mers Frequency

\subsection{Matriks Jarak}

Setelah dilakukan penggunaan N-mers Frequency, tahapan selanjutnya adalah membentuk matriks jarak. Matriks jarak adalah matriks simetri berukuran $n \times n$ yang elemen matriksnya merepresentasikan jarak antar data. Untuk membentuk matriks jarak digunakan persamaan Euclidian distance [12]. Persamaan Euclidian distance dapat dihitung menggunakan rumus yang ditunjukkan pada Persamaan (1),

$$
d_{i k}=\sqrt{\sum_{j=1}^{m}\left(x_{i j}-x_{k j}\right)^{2}}
$$

$$
\begin{array}{cl}
\text { dengan, } & \\
d_{i k} & =\text { jarak data ke-i dan ke- } k \\
m & =\text { dimensi data } \\
x_{i j} & =\text { koordinat dari data ke- } i \text { pada dimensi } j \\
x_{k j} & =\text { koordinat dari data ke- } k \text { pada dimensi } j
\end{array}
$$

Syntax untuk menghitung matriks jarak pada software R ditunjukkan pada Gambar 6. 
mj <- as.matrix(dist (eks, method="euclidean"))

Gambar 6. Syntax untuk menghitung matriks jarak

\subsection{Algoritma Pengelompokan}

Setelah membentuk matriks jarak, matriks tersebut sebagai input algoritma pengelompokan atau clastering. Pengelompokan ini bertujuan untuk menghitung akurasi dari penggunaan $N$-mers Frequency. Data yang akan dikelompokkan adalah data yang sudah diketahui kelompoknya masing-masing. Sebelum dikelompokkan data yang sudah diketahui kelompoknya akan dikumpulkan dan diacak, setelah itu baru dilakukan pengelompokan kembali.

Berdasarkan cara membaginya metode clustering terbagi menjadi dua, yaitu metode partitioning (nonhierarchical) dan metode hierarchical. Metode hierarchical terbagi menjadi dua yaitu, Agglomerative Nesting (AGNES) dan Divisive Analysis (DIANA). Adapun untuk metode partitioning terdiri dari Self Organizing Maps (SOM), Partitioning Around Medoid (PAM), Fuzzy Analysis (FANY) dan K-means [12]. Pada penelitian ini ditentukan 4 algoritma pengelompokan yang memiliki akurasi tinggi yaitu, metode partitioning yang terdiri atas (1) algoritma K-means++ dan (2) algoritma PAM, dan metode hierarchical yang terdiri atas (3) algoritma AGNES dan (4) algoritma DIANA.

\subsubsection{Algoritma K-means++}

Algoritma K-means dapat dilihat pada Algoritma 1.

Algoritma 1. Algoritma K-means

Input: $n$ kelompok data yang akan diklaster,

Output: $K$ klaster, kelompok data dengan label $n$

Steps:

1) Tentukan jumlah klaster (K),

2) Tentukan centroid (titik pusat kalster) secara random.

3) Hitung jarak setiap data ke centroid.

4) Kelompokan objek berdasarkan jarak minimum ke centroid.

5) Hitung centroid baru.

6) Ulangi langkah 3) sampai dengan 5) hingga centroid tidak berubah.

Salah satu kelebihan metode K-means adalah mampu melakukan clustering objek besar dengan sangat cepat sehingga metode ini sangat umum digunakan. Namun karena centroid dilakukan secara acak, memungkinkan hasil pengelompokan bersifat tidak unik (selalu berubah-ubah), sehingga keakuratannya tidak terjamin. Oleh karena itu, disarankan menggunakan algoritma $\mathrm{K}$-means++ yang merupakan perbaikan dari algoritma K-means. Algoritma K-means++ melakukan pemilihan centroid secara acak sebanyak $n$ kali, sedangkat algoritma $k$-mean hanya melakukan pemilihan centroid secara acak sebanyak 1 kali. Pemilihan centroid secara random sebanyak $n$ kali pada software $\mathrm{R}$ disebut $n s t a r t$. Dengan penambahan perhitungan $n$ start pada algoritma $\mathrm{K}$ means++ menghasilkan hasil klaster yang unik, dengan mengambil hasil perhitungan yang mempunyai nilai minimum residual sebagai hasil klaster [13]. Syntax untuk Menghitung algoritma K-means++ pada software R ditunjukkan pada Gambar 7. 


$$
\mathrm{km}<- \text { kmeans (eks, 4, iter. } \max =100 \text {, nstart }=100 \text { ) }
$$

Gambar 7. Syntax untuk menghitung algoritma K-means++

\subsubsection{Algoritma PAM (Partitioning Around Medoid)}

Algoritma PAM atau K-Medoids dapat dilihat pada Algoritma 2.

\section{Algoritma 2. Algoritma PAM [14] [15]}

Input: $n$ kelompok data yang akan diklaster,

Output: K klaster, kelompok data dengan label $n$

Steps:

1) Tentukan jumlah klaster $(K)$.

2) Tentukan medoid secara acak. Medoid merupakan data yang terpilih untuk mewakili klaster.

3) Hitung jarak setiap data non medoid ke medoid.

4) Kelompokan objek berdasarkan jarak minimum ke medoid.

5) Hitung total distance.

6) Ulangi langkah 2) sampai dengan 5) hingga total distance baru - total distance lama $<0$.

Syntax untuk Menghitung algoritma PAM pada software R ditunjukkan pada Gambar 8.

$$
\text { pm <- pam (data, 4, diss = TRUE) }
$$

Gambar 8. Syntax untuk menghitung algoritma PAM

\subsubsection{Algoritma AGNES (Agglomerative Nesting)}

Algoritma AGNES menggunkan Average Linkage ditunjukkan pada Algoritma 3.

\section{Algoritma 3. Algoritma AGNES [5]}

Input: Matriks Jarak

Output: Dendogram

Steps:

1) Gabungkan dua kelompok yang terdekat, misalkan jarak kelompok $U$ dan $V$ adalah yang paling dekat, namakan dengan $d_{u v}$.

2) Gabungkan kelompok U dan V, namakan kelompok baru tersebut dengan (UV).

3) Hitung jarak antara (UV) dan kelompok baru (W) dengan rumus pada Persamaan 2.

$$
d_{(U V)}=\frac{\sum_{i} \sum_{k} d_{i k}}{N_{(U V)} N_{W}}
$$

$$
\begin{aligned}
& \text { dengan, } \\
& \begin{aligned}
d_{i k}= & \text { jarak antara spesies } i \text { dalam kelompok }(U V) \text { dan spesies } k \\
& \text { dalam kelompok } W \\
N_{U V}= & \text { banyaknya data dalam kelompok }(U V) \\
N_{w}= & \text { banyaknya data dalam kelompok } W
\end{aligned}
\end{aligned}
$$


4) Ulangi langkah 1 sampai 3 sampai memperoleh klaster yang dikehendaki atau semua data telah berada dalam kelompok tunggal.

Syntax untuk Menghitung algoritma AGNES pada software $\mathrm{R}$ ditunjukkan pada Gambar 9.

$$
M=\operatorname{agnes}(\text { data, } \text { metric }=\text { "euclidean", stand }=\text { TRUE })
$$

Gambar 9. Syntax untuk menghitung algoritma AGNES

\subsubsection{Algoritma DIANA (Divisive Analysis)}

Algoritma DIANA ditunjukkan pada Algoritma 4.

Algoritma 4. Algoritma DIANA [13][16]

Input: Matriks Jarak

Output: Dendogram

Steps:

1) Tentukan objek yang memiliki nilai rata-rata disimilaritas terbesar, objek tersebut akan dipisah menjadi klaster baru dan menjadi splinter group.

2) Untuk setiap objek $i$ diluar splinter group, hitung selisih nilai antara elemen matriks splinter group dengan nilai rata-rata setiap sekuens yang tersisa, dengan rumus

$$
\left.D_{i}=\text { [average } d(i, j) j \notin R \text { splinter group }\right]-[\text { average } d(i, j) j \in R \text { splinter group] }
$$

3) Tentukan objek yang memiliki nilai selisih terbesar antara elemen matriks splinter group dengan nilai rata-rata. Jika nilai selisih tersebut bernilai positif, maka objek yang memiliki nilai selisih terbesar bergabung dengan splinter group.

4) Ulangi langkah 2 dan 3 sedemikian sehingga semua nilai selisih antara elemen matriks splinter group dengan nilai rata-rata bernilai negatif. Maka klaster terbagi menjadi dua klaster baru.

5) Pilih klaster dengan diameter terbesar. Diameter klaster merupakan disimilaritas terbesar antara sebarang dua objek dalam satu klaster. Kemudian bagi klaster ini, mengikuti langkah 1 sampai 4 .

6) Ulangi langkah 5 sampai memperoleh klaster yang dikehendaki atau semua klaster telah berisi satu objek.

Syntax untuk Menghitung algoritma DIANA pada software $\mathrm{R}$ ditunjukkan pada Gambar 10.

$$
M<- \text { diana(data, metric = "Euclidean", stand = TRUE) }
$$

Gambar 10. Syntax untuk menghitung algoritma DIANA 


\subsection{Menghitung Akurasi}

Untuk menghitung akurasi penggunaan N-mers Frequency, data yang sudah diketahui jenisnya akan diacak, kemudian dikelompokkan kembali. Data yang tidak kembali pada kelompoknya akan dihitung, dan akan dihitung persentasenya. Untuk 100 data, Misalkan ada satu data yang tidak mengelompok dengan benar, maka bisa dikatakan $1 \%$ tidak akurat, atau dengan kata lain keakuratannya 99\%. Persentase akurasi penggunaan $\mathrm{N}$-mers Frequency dapat dihitung dengan menggunakan rumus pada Persamaan (3).

dengan,

$$
\% A=\frac{x}{100} \times 100 \%
$$

$\% A \quad=$ persentase akurasi penggunaan $N$-mers Frequency

$x \quad=$ banyaknya data yang mengelompok ke kelompoknya kembali.

\section{Hasil dan Pembahasan}

\subsection{Data Penelitian}

Data barisan DNA HPV yang berupa data string dibaca menggunakan software $\mathrm{R}$ dengan fungsi readDNAStringSet pada library "Biostrings". Hasil readDNAStringSet berupa tabel yang memisahkan panjang barisan DNA (width), barisan DNA (seq) dan diskripsi data (name). Hasil readDNAStringSet dapat dilihat pada Gambar 11.

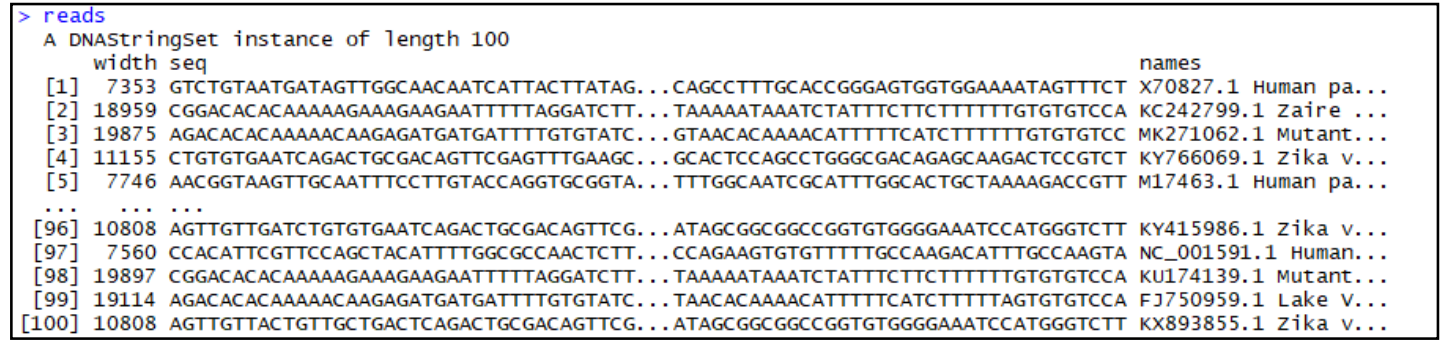

\section{Gambar 11. Hasil readDNAStringSet}

\subsection{Hasil N-mers Frequency}

Untuk mengubah data barisan DNA HPV yang berupa data string menjadi data numerik, digunakan $N$-mers Frequency. Dengan menentukan $N=3$, diperoleh dimensi data sebesar $4^{3}=64$. Dengan demikian, data memiliki 64 atribut atau dimensi. Pada Gambar 12 ditunjukkan hasil N-mers Frequency dari 100 barisan DNA menggunakan software R dengan hasil Ekstraksi ciri berupa matriks yang berukuran $100 \times 64$.

\begin{tabular}{|c|c|c|c|c|c|c|c|c|c|c|c|c|c|c|c|c|c|}
\hline$\wedge$ & AAA & AAC & AAG & AAT & ACA & ACC & ACG & ACT & AGA & AGC & AGG & AGT & ATA & ATC & ATG & АП & CAA \\
\hline 1 & 261 & 126 & 154 & 215 & 165 & 84 & 52 & 103 & 214 & 88 & 116 & 136 & 180 & 97 & 152 & 220 & $\wedge$ \\
\hline 2 & 617 & 415 & 407 & 533 & 502 & 281 & 136 & 316 & 424 & 247 & 294 & 289 & 356 & 386 & 329 & 521 & \\
\hline 3 & 672 & 422 & 455 & 588 & 502 & 262 & 111 & 341 & 438 & 218 & 295 & 296 & 428 & 391 & 377 & 582 & \\
\hline 4 & 244 & 165 & 287 & 134 & 239 & 153 & 85 & 169 & 320 & 201 & 263 & 163 & 108 & 143 & 257 & 117 & \\
\hline 5 & 234 & 134 & 184 & 172 & 199 & 92 & 54 & 115 & 177 & 105 & 170 & 115 & 174 & 103 & 130 & 218 & \\
\hline 6 & 613 & 410 & 410 & 528 & 496 & 278 & 137 & 324 & 423 & 243 & 291 & 296 & 354 & 390 & 325 & 520 & \\
\hline 7 & 697 & 386 & 440 & 595 & 470 & 223 & 99 & 316 & 410 & 216 & 282 & 298 & 418 & 393 & 364 & 565 & \\
\hline 8 & 234 & 157 & 284 & 136 & 257 & 164 & 75 & 153 & 324 & 199 & 273 & 175 & 106 & 149 & 282 & 108 & \\
\hline 9 & 253 & 181 & 131 & 179 & 275 & 114 & 67 & 106 & 125 & 81 & 124 & 118 & 232 & 68 & 215 & 218 & $\checkmark$ \\
\hline & & & & & & & & & & & & & & & & & \\
\hline
\end{tabular}

Gambar 12. Hasil N-mers Frequency 


\subsection{Hasil Perhitungan Matriks Jarak}

Untuk membentuk matriks jarak digunakan persamaan Euclidian distance. Pada Gambar 13 ditunjukkan hasil perhitungan matriks jarak dari 100 barisan DNA menggunakan software $\mathrm{R}$, menghasilkan matriks berukuran $100 \times 100$.

\begin{tabular}{|c|c|c|c|c|c|c|c|c|c|c|c|c|c|}
\hline \multicolumn{12}{|c|}{\begin{tabular}{l|l|l|l|l|l|} 
& Filter
\end{tabular}} & \multicolumn{2}{|l|}{ a } \\
\hline$\Delta$ & $1 \div$ & 2 & $\hat{*}$ & 4 & 5 & $\hat{\imath}$ & $\hat{*}$ & 8 & $\hat{\imath}$ & 10 & 11 & 12 & 13 \\
\hline 1 & 0.00000 & 1576.921051 & 1733.2905 & 805.17079 & 187.64061 & 1573.72679 & 1652.292952 & 823.98544 & 349.13608 & 1577.075141 & 1652.103810 & 776.82752 & $206.55 \wedge$ \\
\hline 2 & 1576.92105 & 0.000000 & 316.1835 & 1366.11713 & 1551.57694 & 37.97368 & 319.924991 & 1375.84592 & 1560.57041 & 2.000000 & 320.320152 & 1390.07806 & 1568.74 \\
\hline 3 & 1733.29051 & 316.183491 & 0.0000 & 1581.37662 & 1723.90922 & 324.29308 & 142.975522 & 1591.44086 & 1713.00905 & 315.772070 & 143.230583 & 1603.17404 & 1745.83 \\
\hline 4 & 805.17079 & 1366.117125 & 1581.3766 & 0.00000 & 721.67791 & 1358.93341 & 1531.220428 & 91.54234 & 827.78620 & 1366.409163 & 1530.978445 & 48.36321 & 706.79 \\
\hline 5 & 187.64061 & 1551.576940 & 1723.9092 & 721.67791 & 0.00000 & 1548.11014 & 1646.355672 & 744.66570 & 316.55173 & 1551.756746 & 1646.265471 & 692.92568 & 103.27 \\
\hline 6 & 1573.72679 & 37.973675 & 324.2931 & 1358.93341 & 1548.11014 & 0.00000 & 329.226366 & 1369.10263 & 1559.50761 & 38.105118 & 329.743840 & 1383.10701 & 1565.36 \\
\hline 7 & 1652.29295 & 319.924991 & 142,9755 & 1531.22043 & 1646.35567 & 329.22637 & 0.000000 & 1542.51094 & 1638.71291 & 319.374388 & 4.795832 & 1551.86887 & 1669.16 \\
\hline 8 & 823.98544 & 1375.845922 & 1591.4409 & 91.54234 & 744.66570 & 1369.10263 & 1542.510940 & 0.00000 & 841.10760 & 1376.139528 & 1542.290180 & 107.90273 & 727.69 \\
\hline 9 & 349.13608 & 1560.570409 & 1713.0090 & 827.78620 & 316.55173 & 1559.50761 & 1638.712910 & 841.10760 & 0.00000 & 1560.694717 & 1638.554546 & 801.86470 & $316.97 \checkmark$ \\
\hline$<$ & & & & & & & & & & & & & $>$ \\
\hline
\end{tabular}

Gambar 13. Hasil perhitungan matriks jarak

\subsection{Hasil Pengelompokan}

Setelah diperoleh hasil perhitungan matriks jarak, tahap selanjutnnya adalah pengelompokan 100 barisan DNA yang sudah diacak. Pengelompokan yang dilakukan menggunakan algoritma K-means++, PAM, AGNES, dan DIANA. Dilakukan pengelompokan sebanyak 4 kelompok, hal ini didasarkan pada kelompok yang telah ditentukan sebelumnya, yaitu virus HPV, Ebola, Marburg, Zika. Hasil pengelompokan masing-masing ditunjukkan pada Gambar 14 s.d Gambar 17.

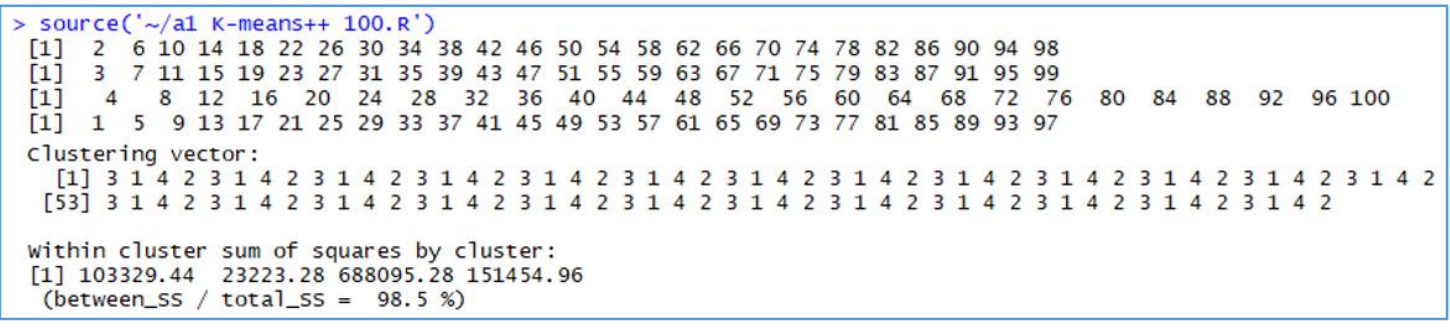

Gambar 14. Hasil pengelompokan menggunakan algoritma K-means++

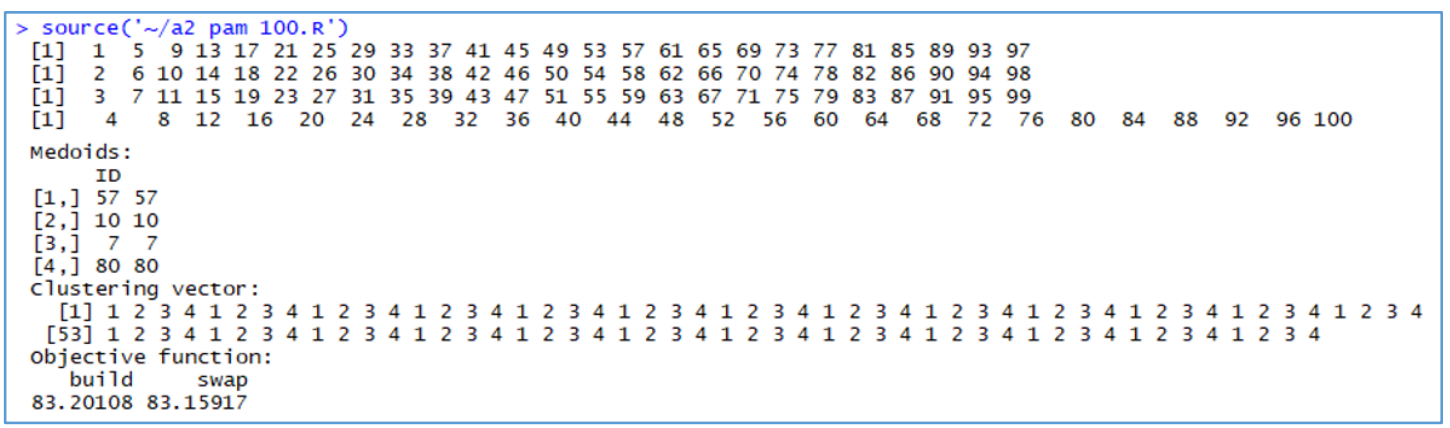

Gambar 15. Hasil pengelompokan menggunakan algoritma PAM 


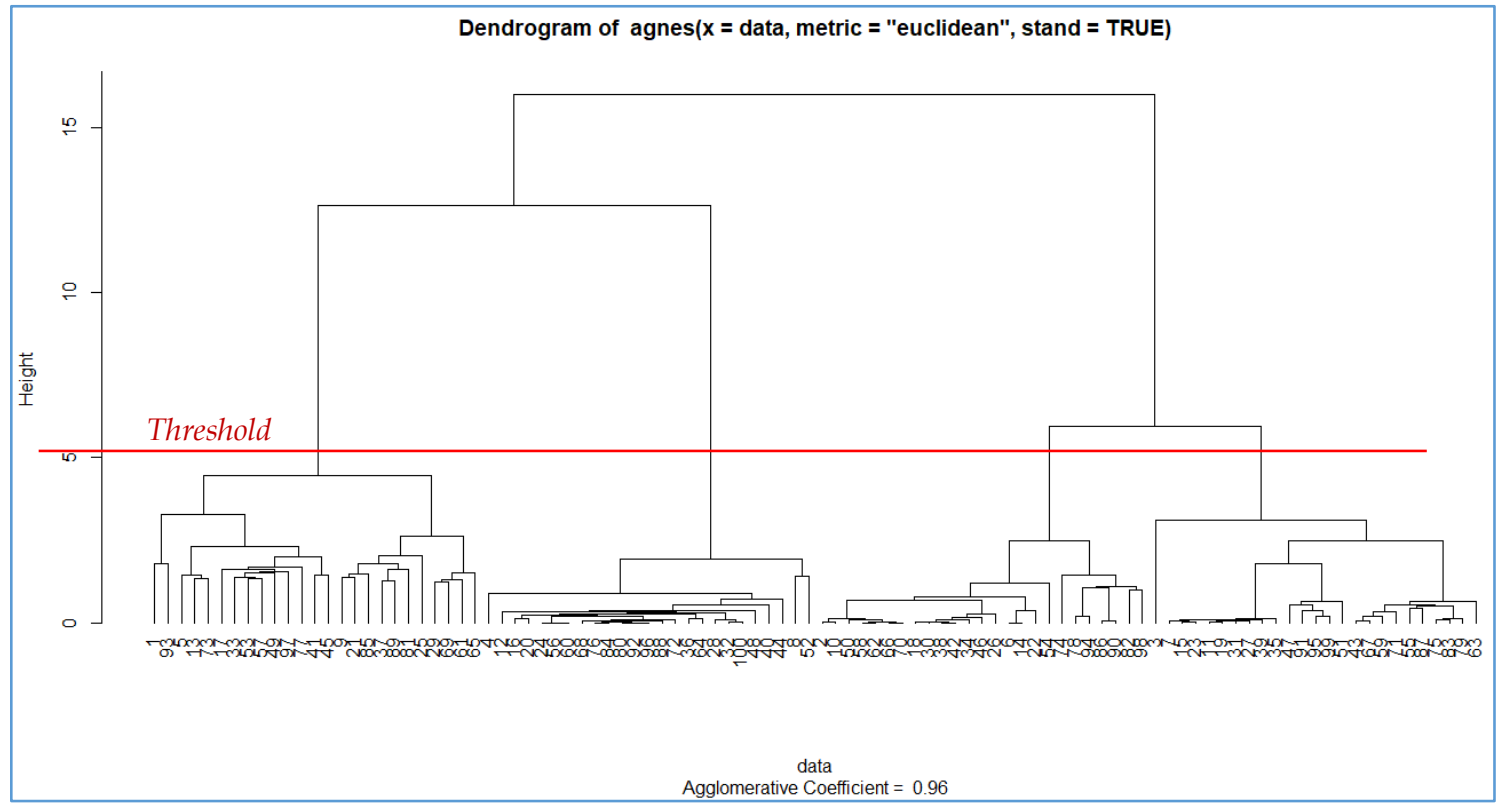

Gambar 16. Dendogram hasil pengelompokan menggunakan algoritma AGNES

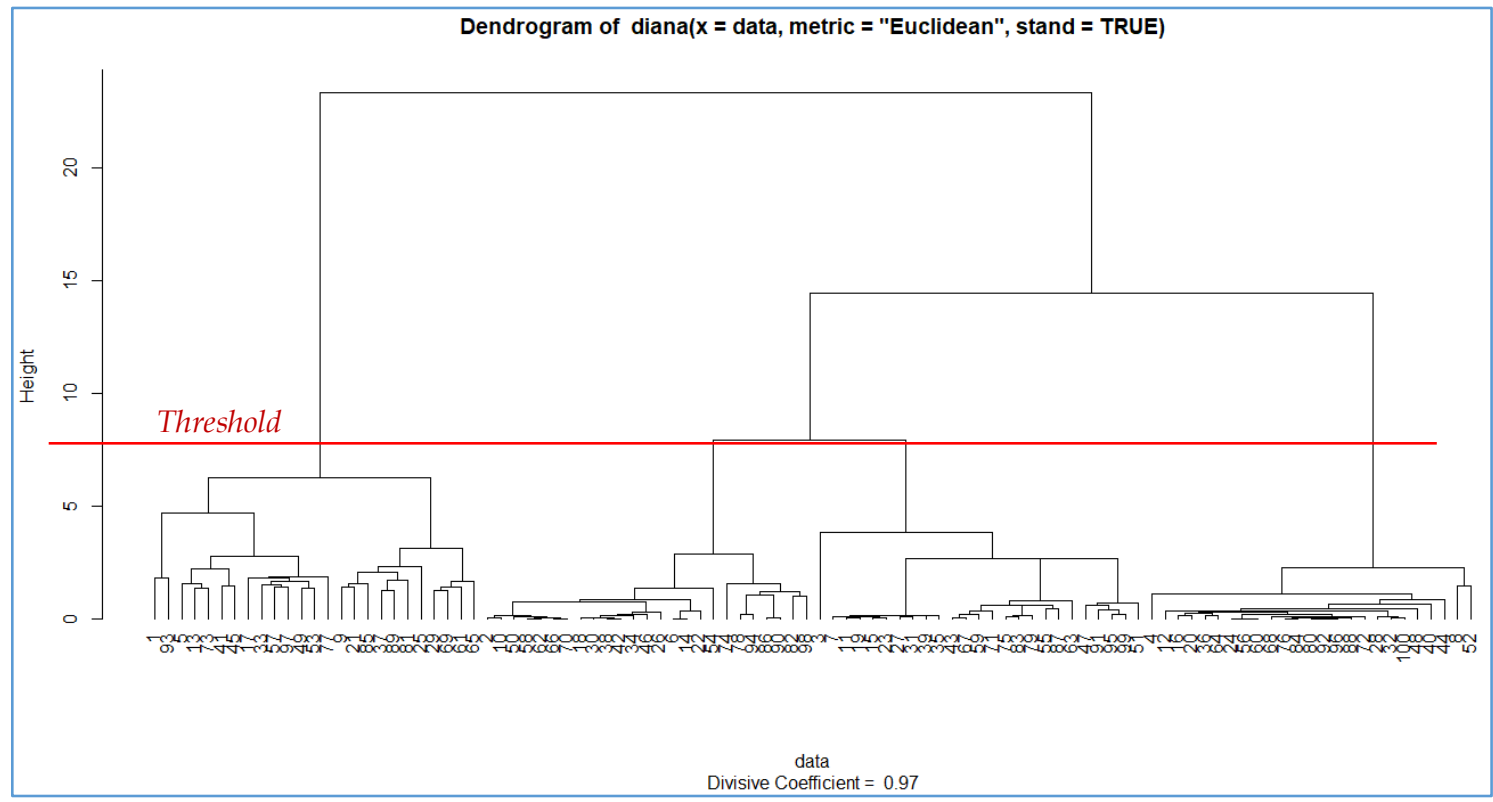

Gambar 17. Dendogram hasil pengelompokan menggunakan algoritma DIANA

Pada Gambar 16 dan Gambar 17 ditentukan sebuah threshold yang memotong Dendogram menjadi 4 kelompok dikarenakan kelompok yang ditetapkan sebelumnya adalah 4 kelompok. Dilihat dari Agglomerative Coefficient $=0.96$ dan Divisive Coefficient $=$ 0.97 pengelompokan yang terbentuk sangat baik. Hal tersebut juga dikonfirmasi oleh hasil pengelompokan algoritma K-means++ pada Gambar 14, bahwa persentase perbandingan between_SS dan total_SS sebesar 98,5\% yang menunjukkan bahwa pengelompokan tersebut sangat baik.

Dari keseluruhan hasil pengelompokan menggunakan algoritma K-means++, PAM, AGNES, dan DIANA pada Gambar 14 sampai 17, diperoleh 4 klaster sama. Anggota 
masing-masing klaster yang telah diurutkan disajikan pada Tabel 1.

Tabel 1. Hasil pengelompokan

\begin{tabular}{cl}
\hline Klaster & \multicolumn{1}{c}{ Barisan DNA ke } \\
\hline Klaster 1 - Ebola & 26101418222630343842465054586266707478828 \\
(25 anggota) & 6909498 \\
Klaster 2 - Marburg & 37111519232731353943475155596367717579838 \\
(25 anggota) & 7919599 \\
Klaster 3 - Zika & 481216202428323640444852566064687276 \\
25 anggota & 8084889296100 \\
& 15913172125293337414549535761656973778185 \\
Klaster 4 - HPV & 15993 \\
(25 anggota) & 899397 \\
\hline
\end{tabular}

Dari Tabel 1, diperoleh informasi bahwa Klaster 1 merupakan pengelompokan barisan DNA virus Ebola, Klaster 2 merupakan pengelompokan barisan DNA virus Marburg, Klaster 3 merupakan pengelompokan barisan DNA virus Zika, dan Klaster 4 merupakan pengelompokan barisan DNA virus HPV.

\subsection{Hasil Perhitungan Akurasi}

Hasil perhitungan akurasi secara detail disajikan pada Tabel 2.

Tabel 2. Hasil perhitungan akurasi

\begin{tabular}{cc}
\hline Algoritma & Akurasi \\
\hline K-means++ & $100 \%$ \\
PAM & $100 \%$ \\
AGNES & $100 \%$ \\
DIANA & $100 \%$ \\
\hline Rata-rata & $100 \%$ \\
\hline
\end{tabular}

Dari Tabel 2 terlihat Akurasi dari berbagai pengelompokan menggunakan algoritma Kmeans++, PAM, AGNES, dan DIANA adalah 100\%, sehingga diperoleh rata-rata $100 \%$. Dengan kata lain tidak ada satupun barisan DNA yang salah dalam penentuan klasternya. Hal ini menunjukkan bahwa N-mers Frequency sangat baik digunakan dalam analisis barisan DNA.

Akurasi tinggi ini dikarenakan oleh konversi dari data string ke data numerik dengan bahwa $N$-mers Frequency dengan $N=3$ yang dilandasi oleh teori proses sintesis, dimana hasil dari N-mers Frequency merupakan data yang mempunyai 64 dimensi yang elemennya mewakili jumlah kodon pembentuk protein. Oleh karena itu, ketika dilakukan clustering atau analisis lainnya akan diperoleh hasil yang baik.

\section{Kesimpulan}

Akurasi penggunaan $N$-mers Frequency dalam kasus ini menggunakan 100 barisan DNA mempunyai akurasi yang sangat baik yaitu 100\%. Tidak ada satupun barisan 
DNA yang salah dalam penentuan kelompoknya kembali. Klaster 1 adalah pengelompokan barisan DNA virus Ebola, Klaster 2 adalah pengelompokan barisan DNA virus Marburg, Klaster 3 adalah pengelompokan barisan DNA virus Zika, dan Klaster 4 adalah pengelompokan barisan DNA virus HPV.

\section{Ucapan Terimakasih}

Terima kasih kepada Institut dan Teknologi Bisnis Kalbis yang telah membantu pembiayaan dalam penelitian ini dan menyediakan sarana dan prasarana pada pelaksanaan penelitian.

\section{Referensi}

[1] A. Lucassen, J. Montgomery, and M. Parker, "Ethics and the Social Contract for Genomics in the NHS," 2017.

[2] NCBI, "National Center for Biotechnology Information," U.S. National Library of Medicine. [Online]. Available: https://www.ncbi.nlm.nih.gov. [Accessed: 15Feb-2018].

[3] Xinhua, "China to Create Gigantic DNA Database," 2017. [Online]. Available: http://www.chinadaily.com.cn/china/2017-10/31/content_33930020.htm.

[Accessed: 22-Oct-2018].

[4] B. Chor, D. Horn, N. Goldman, Y. Levy, and T. Massingham, "Genomic DNA kmer spectra: models and modalities," Genome Biol., vol. 10, no. 10, p. R108, 2009.

[5] A. Bustamam, I. Fitria, and K. Umam, "Application of Agglomerative Clustering for Analyzing Phylogenetically on Bacterium of Saliva," in AIP Conference Proceedings, 2017, p. 030126.

[6] S. M. Gollin, "Epidemiology of HPV-Associated Oropharyngeal Squamous Cell Carcinoma," in Human Papillomavirus (HPV)-Associated Oropharyngeal Cancer, D. L. Miller and M. S. Stack, Eds. Cham: Springer International Publishing, 2015, pp. 1-23.

[7] E. Mühlberger, "Genome Organization, Replication, and Transcription of Filoviruses," in Ebola and Marburg Viruses: Molecular and Cellular Biology, H.-D. Klenk and H. Feldmann, Eds. Winnipeg: Horizon Bioscience, 2004.

[8] S. R. da Silva, F. Cheng, and S.-J. Gao, Zika Virus and Diseases. Hoboken, NJ, USA: John Wiley \& Sons, Inc., 2018.

[9] NCBI, "Nucleotide - National Center for Biotechnology Information," U.S. National Library of Medicine. [Online]. Available: https://www.ncbi.nlm.nih.gov/nuccore. [Accessed: 15-Feb-2018].

[10] D. W. Mount, Bioinformatics: Sequence and Genome Analysis, 2nd ed. Tucson: Cold Spring Harbor Laboratory Press, 2004.

[11] K. Umam, A. Bustamam, and D. Lestari, “Application of hybrid clustering using parallel k-means algorithm and DIANA algorithm," in AIP Conference Proceedings, 2017, p. 020024.

[12] L. Kaufman and P. J. Rousseeuw, Finding Groups in Data: An Introduction to Cluster Analysis. Hoboken, NJ, USA: John Wiley \& Sons, Inc., 1990. 
[13] C. C. Aggarwal and C. K. Reddy, Data Clustering: Algorithms and Applications, 1st ed. CRC Press, 2013.

[14] D. Arthur and S. Vassilvitskii, "K-Means++: The Advantages of Careful Seeding," in Proceedings of the Eighteenth Annual ACM-SIAM Symposium on Discrete Algorithms, 2007.

[15] R. D. Cahyaningrum, A. Bustamam, and T. Siswantining, "Implementation of spectral clustering with partitioning around medoids (PAM) algorithm on microarray data of carcinoma," in AIP Conference Proceedings, 2017, p. 020007.

[16] J. Han, M. Kamber, and J. Pei, Data Mining: Concepts and Techniques, 3rd ed. Waltham: Morgan Kaufmann Publishers, 2012. 